\title{
Daily Milk Production in Cows: The Effect on the Concentration Level of Total Cholesterol in Blood Serum
}

\author{
Muhamed Katica ${ }^{1 *}$, Adis Mukača ${ }^{2}$, Ermin Saljic ${ }^{3}$ and Kenan Čaklovica ${ }^{4}$ \\ ${ }^{1}$ Department of Pathological Physiology of Domestic Animals, University of Sarajevo, Europe \\ ${ }^{2}$ Cantonal Veterinary Inspection of the Zenica-Doboj Canton, Europe \\ ${ }^{3}$ Clinic for Internal Diseases, University of Sarajevo, Europe \\ ${ }^{4}$ Department of Food Hygiene and Technology, University of Sarajevo, Europe
}

Submission: May 31, 2019; Published: June 18, 2019

*Corresponding author: Muhamed Katica, Veterinary Faculty, Department of Pathophysiology, University of Sarajevo, Zmaja od Bosne no. 90,71000 Sarajevo, Bosnia and Herzegovina, Europe

\begin{abstract}
The modern way of cultivation, that is, the technology used for keeping and exploitation of dairy cows, is aimed at continuous increase in the intensity of milk production and maximizing the use of genetically high milk. The burden on the metabolism of high-productive cows is most evident in late gravidity and puerperium. The link between the production characteristics of high-producing dairy cows (daily milk production) and the metabolic capacity of their organism is still insufficiently clear, and so a legitimate reason for the research. The concentration of total cholesterol in the blood serum of cows in lactation varies in a wide range (1.3-9.36 mmol / L). Many internal and external factors affect the elevated or decreased level of total cholesterol concentration in blood serum of lactating cows. According to the recent studies, the amount of daily milk production of cows who lived in farm conditions of breeding and keeping, does not have a significant effect on the level of total cholesterol in the blood serum, what was determined using single linear regression analysis.
\end{abstract}

Keywords: Cow in Lactation; Milk; Daily milk production; Total cholesterol

\section{Introduction}

Maintaining dairy cows in high lactation and good health are the main priorities of modern breeding, while the control of nutritional metabolic status is of great importance. The metabolic overload of highly productive cows is most evident in late pregnancy and puerperium. Given the needs of cows in the last two months of gravity, and especially during the early lactation period during the winter, the meals are often not well and rationally balanced, both in terms of selecting nutrients and in terms of energy content, such as: proteins, dry matter and cellulose [1]. Numerous environmental factors affect the production of milk in cows, which are: ambient temperature, humidity, solar radiation and wind [2]. Different levels of feeding with and without added fat should have different repercussions on biochemical parameters of blood, as well as on the quality of milk produced [3]. Our article was intended to point out the possible correlation and possible impact of daily milk production on changing levels of total cholesterol concentration in lactating cows' blood serum.
Total Cholesterol Level in the Blood Serum of Lactating Cows

Cholesterol, together with phospholipids, is an integral part of all cell membranes; it participates in the construction of myelinating nerve wrap and presents a starting substance for the synthesis of bile acids, steroid hormones of the adrenal and sex glands, and vitamin D3. In the cow tissue, cholesterol can be found in a free and bound form as an ester with higher fatty acids. In membrane structures, it is most often found in an unesterified form [4]. The total cholesterol concentration in the cow serum varies widely and ranges from 1.3 to $6.0 \mathrm{mmol} / \mathrm{L}$ and is associated with age, physiological state, production characteristics, and nutrition [3]. According to Mukača, whose sample were 62 tested cows, and tested was the total cholesterol concentration in the blood serum of cows, the values obtained varied in the range from 2.25 to $9.36 \mathrm{mmol} / \mathrm{L}$. Other literature references correlate with the already mentioned studies, that is, confirm the variation in the 
total cholesterol concentration in the cow serum and they range from 1.3 to $7.3 \mathrm{mmol} / \mathrm{L}$ [5-9]; however, keeping in mind that these studies refer to the winter period sampling of cows' blood serum.

It was also found that the value of cholesterol concentration in cows with different daily milk production varies. According to Mukača there are differences in the concentration of cholesterol between cows with different amounts of daily milk. Additional testing of the significance of these differences revealed that they are statistically significant, but only among cows with daily production of 29-34L milk and cows with daily production of 35-52L milk. Based on the same research, using single linear regression, it has been established that the amount of daily milk production does not have a significant effect on the concentration of total cholesterol in the blood serum.

\section{Factors that Influence the Change in the level of Total Cholesterol in the Cows' Blood Serum}

In the postpartum period, in cows with ketosis, a statistically lower concentration of total cholesterol was found in relation to the average values of cholesterol in the blood of healthy cows after calving [10]. Decreased blood cholesterol levels are closely correlated with energy imbalance that occurs during high gravidity and at the beginning of lactation in high-lactating cows. Every condition that leads to the negative energy balance of cows leads to the mobilization of fatty acids from body reserves and reaches its maximum in the first or second week of lactation. Hormones (growth hormone, insulin, glucagon and cortisol) have an important role in regulating the metabolism of fat as well as carbohydrates and proteins in complex conditions of high milk production and the preservation of the homeostasis of the organism. In such conditions, the relationships between hormones, their concentration in the circulation, as well as the number and sensitivity of the receptors in the target cells which they affect [11] are changing.

\section{Conflict of Interest}

The authors have no conflict of interest to declare

\section{References}

1. Mukača A, Katica M (2018) Effect of daily milk production on plasma calcium, phosphorus and magnesium concentrations in dairy cows. Journal of Istanbul Veterinary Sciences 2(1): 23-29.

2. Marenjak TS, Stipić D, Milas NP, Čolig K (2007) Control of the milk production and total cholesterol concentration, the activity of gammaglutamyl transferase and glutathione peroxidase in the blood of Simmental cows. Mljekarstvo, 57(2): 119-137.

3. Šaljić Ermin (2010) Metabolic profile of cows in lactation in conditions of different levels of diet with added fat. Master's thesis. Faculty of Veterinary Medicine, University of Sarajevo, Bosnia and Herzegovina, Europe.

4. Mukača Adis (2015) Influence of daily milk production on the metabolic profile of cow blood in farm breeding. Master's thesis. Veterinary Faculty, University of Sarajevo, Bosnia and Herzegovina, Europe.

5. Hadžimusić Nejra (2010) Standardization of reference values and biochemical parameters of cow blood in farm breeding. Master's thesis. Veterinary Faculty, University of Sarajevo, Bosnia and Herzegovina, Europe.

6. Dubreuil P, Lapierre H (1997) Biochemistry reference values for Quebec lactating dairy cows, nursing sows, growing pigs and calves. Can J Vet Res 61: 235-239.

7. Krnić J, Podžo M, Hodžić A, Hamamdžić M, Pašić-Juhas E, et al. (2003) Metabolic profile of cows in lactation and peripartally, Veterinaria 52(1-4): 75-86.

8. Yokus B, Cakir DU (2006) Seasonal and Physiological Variations in Serum Chemistry and Mineral Concentrations in Cattle. Biological trace Element Research 109(3): 255-266.

9. Sako T, Urabe S, Kusaba A, Kimura N, Yoshimura I, et al. (2007) Comparison of Plasma Metabolite Concentrations and Lactate Dehydrogenase Activity in Dogs, Casts, Horses, Cattle and Sheep. Veterinary Research Communications 31: 413-417.

10. Đoković R, Šamanc H, Bojkovski J, Borozan S, Bošković- Bogoslavljević S (2007) Morphological and functional state of liver cells in dairy cows in early lactation. Savremena poljoprivreda 56(3-4): 92-97.

11. Radojičić Biljana (1995) Examination of the effect of propionates on cortisol, insulin, glucose and lipid levels in cattle blood. Doctoral dissertation, University of Belgrade, Serbia, Europe.

\section{Your next submission with Juniper Publishers will reach you the below assets}

- Quality Editorial service

- Swift Peer Review

- Reprints availability

- E-prints Service

- Manuscript Podcast for convenient understanding

- Global attainment for your research

- Manuscript accessibility in different formats

( Pdf, E-pub, Full Text, Audio)

- Unceasing customer service

Track the below URL for one-step submission https://juniperpublishers.com/online-submission.php 